\title{
The Born Global Entrepreneur In Emerging Economies
}

Elif S. Persinger, (E-mail: esonmez@emich.edu), Eastern Michigan University Emin Civi, (E-mail: ecivi@unbsj.ca), University of Saint Brunswick, St. John, Canada Suzanne Walsh Vostina, (E-mail: swalsh@emich.edu), Eastern Michigan University

\begin{abstract}
As emerging economies increasingly participate in the global economy, Born Global firms from these countries are becoming significant players as well. In the literature, topics related to Born Global firms from emerging economies have mostly been overlooked. The purpose of this paper is to address part of this gap by studying the Born Global entrepreneur within the context of an emerging market. Specifically, the Born Global entrepreneur's knowledge and behaviors required to start a Born Global firm in an emerging market as well as the success factors in the global marketplace are examined.
\end{abstract}

\section{INTRODUCTION}

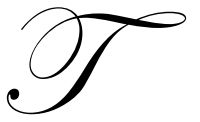

he phenomenon of the Born Global firm first appeared in the business literature over a decade ago. McKinsey \& Co. (McKinsey \& Co. 1993) were the first to identify a group of Australian manufacturers who were exporting just two years after establishment. Typically these manufacturers were producing high value-added products and had not developed a strong home market. This seminal report sparked interest in the business research community and a growing number of researchers are giving attention to the area of the Born Global firm.

The purpose of this paper is to study the Born Global entrepreneur within the context of an emerging market. To date, the studies undertaken of the Born Global phenomenon have focused on industrial economies - the natural birthplace of the Born Global firm given their emphasis on manufacturing and process innovations. As the governments of emerging economies institute the structural changes necessary to more fully participate in the global marketplace, the opportunities for Born Global firms will increase and the likelihood of these types of firms forming in emerging economies will increase as well.

This paper presents a conceptual explanation of a person who would establish a Born Global business within the context of an emerging market. The characteristics of him/her in terms of the knowledge and behaviors required to start a business in an emerging market and be successful in the global marketplace are examined. All emerging markets are not equal. The pace of growth and level of development are important factors in the feasibility of starting a Born Global firm. The issues facing the Born Global entrepreneur are also discussed.

\section{INTERNATIONALIZATION AND THE BORN GLOBAL FIRM}

The internationalization process of firms has been the topic of extensive research in the field of international marketing. Two stage-method models of internationalization have surfaced. The Uppsala internationalization model (Johansen and Vahlne, 1977) and the innovation-related internationalization (I-M) models (Cavusgil, 1980, Bilkey \& Tesar, 1977) consider the internationalization of firms to be a gradual process. These models contend that firms become international in a slow and incremental process. This measured and deliberate pattern is due to a lack of knowledge about foreign markets, risk-avoiding management, perceived uncertainty or other similar braking factors. The theories diverge in their analysis of the internationalization process. The Uppsala model sees internationalization as an organizational learning process. The I-M model sees internationalization as an innovation of the firm. The stage 
approach to internationalization has been well documented and finds support in business practice. However, these models are insufficient to describe the growing number of firms that are providing goods and services globally from birth - the Born Global firm.

During the last 15 years new empirical studies of the export behavior of firms have challenged with many findings of actual export behavior reported in the traditional internationalization literature. It has been demonstrated that many firms now do not grow in incremental stages with respect to their international activities. Some small and medium sized businesses internationalize immediately at a very early stage in their organizational life (McKinsey \& Co, 1993; Knight, 1997; Knight and Cavusgil, 1996; Coviello and Munro, 1995; McDougall, Shane and Oviatt, 1994; Oviatt and McDougall, 1994; Oviatt and McDougall, 1997 and Yip, Biscarri and Monti, 2000). The internationalization methods of these small firms are completely dissimilar to that of firms normally monitored in the earlier period. The way these small firms follow to export their products is different from as explained in existing internationalization theories namely the stages model. As pointed out by Hadjikhani and Johanson (2002), the stages model is still considered as able to explain the internationalization process for firms.

Over the past 15 years, there have been an increasing number of researches done to study the internalization of newly established companies which implement a global strategy from their inception that is not consistent with the traditional expectations (Knight, 1997; Oviatt and McDougall, 1994). Knight and Cavusgil (1996) have stated that "the new phenomenon presents an important new challenge to traditional internationalization theory." Cavusgil (1994) goes further and claims that "gradual internationalization is dead". Such companies have been named as Born Globals by (Rennie, 1993; Knight \& Cavusgil, 1996; Madsen \& Servais, 1997), Global Start-ups by (Oviatt \& McDougall, 1994), High Technology Start-ups by (Jolly, Alahuta \& Jeannet, 1992), Infant Multinationals by (Lindqvist, 1991), Instant internationals (Preece, Miles \& Baetz, 1999) and International New Ventures by (McDougall, Shane \& Oviatt, 1994). In this paper, we prefer to use the term "Born Global".

The concept of born globals was first used by McKinsey while doing a survey for the Australian Manufacturing Council (McKinsey \& Co., 1993). In this study, a born-global firm were defined as "one which views the world as their marketplace from the outset; they do not see foreign markets as useful adjuncts to the domestic market". According to Cavusgil \& Knight (1997), Born Global firms are generally small, have less than 500 employees and their annual sales are under $\$ 100$ million. These firms begin exporting one or several products within two years of their establishment and tend to export at least $25 \%$ of total production.

Cavusgil and Knight's (1996) definition of the Born Global firm makes sense within the context of a developed and large economy. A less aggressive model may be more appropriate for an emerging economy. A Born Global firm within this context will likely have annual sales of less than $\$ 50$ million, less than 500 employees and achieve a $25 \%$ export rate no earlier than three or four years after the inception of the firm. The ability to raise capital, develop networks and understand targeted niche markets will take longer. Information may be available as quickly in an emerging economy as it is in a developed economy, but the path to fully exploiting that information has a set of roadblocks specific to the emerging market environment. Thus, the ability to achieve the higher end of less than $\$ 100$ million in sales and export $25 \%$ of production within two years may be an impossible marker for the emerging market Born Global firm. As noted by Gartner (1985):

"New venture creation is a complex phenomenon: entrepreneurs and their firms vary widely; the actions they take or do not take and the environments they operate in and respond to are equally diverse - and all these elements form complex and unique combinations in the creation of each new venture."

Firms studied early in the phenomenon showed a reliance on advanced technology and found market advantage through product or process innovations (Cavusgil \& Knight, 1997). A narrow definition of the born global firm as a manufacturing concern is limited in scope. Over time, more and more non-manufacturing firms will fit the definition of "born global" (Oviatt \& McDougall, 1994). Born Global firms operate in knowledge-intensive environments and give little or no attention to their home market (Bell, McNaughton, Young \& Crick, 2003). Hence, building a sizable home market advantage is not a part of the firm's strategy. All resources are devoted to the international marketplace. The nature of the firm departs from traditional internationalization models in nearly every 
way possible. The firm's motivation is driven by a globally committed management and their desire to serve small, dispersed niche markets; the development of more and more dispersed niche markets is expected to grow. The firm's expansion patterns and pace of expansion are both rapid and multidirectional - penetration of multiple markets simultaneously is common, if not expected because of the size of the niche markets (Bell, McNaughton, Young \& Crick, 2003).

With this definition of the Born Global firm, is it suitable for an emerging market? Can it be fully applied within that context? Andersson and Victor (2003) feel that nations with small domestic markets have a higher propensity to generate Born Globals than firms in nations with large domestic markets. Although the first cases of the Born Global involved high-tech and/or manufacturing, Born Globals from smaller economies/countries are found in a variety of industries (Andersson and Victor, 2003). Given the more limited technology capabilities and manufacturing facilities available in an emerging market, entrepreneurs from these economies will certainly find alternative avenues to build Born Global firms.

\section{MOTIVES AND CHARACTERISTICS OF BORN GLOBAL FIRM}

Motives for the rapid internationalization of 'born global' firms are numerous. Knight and Cavusgil (1996) indicated different factors facilitating the Born Global expansion. The increasing role of niche markets and greater demand for specialized or customized products is one of the most important factors. Shorter product life cycles is another factor causing born global firms to adopt an international perspective regardless of their age and size (Ohmae, 1990 and Oviatt and McDougall, 1997). These factors together have helped SMEs to consider exporting their product and getting internationalize in their early age. Other important factors triggering the emergence of Born Global firms are significant advances in the production, transportation and communication areas, the increased importance of global networks and alliances, and more elaborate capabilities of people, including those of the founder/entrepreneur who starts early internationalizing firms (Knight and Cavusgil, 1996, Madsen and Servais, 1997, Moen, 2002 and Servais and Rasmussen, 2000).

As Knight and Cavusgil ( 2004), Born Globals are emerging in substantial numbers worldwide, and likely reflect an emergent paradigm, with the potential to become a leading species in the ecosystem of international trade. In this sense, the born-global phenomenon is heartening because it implies the emergence of an international exchange system in which any firm, regardless of age, experience, and tangible resources, can be an active international business participant. Although large global corporations and the negative aspects of globalization often dominate reports in the popular press with respect to the emergent world order, the increasing role of born globals implies a more optimistic view. In relative terms, born globals might be seen to herald a more diverse international business system in which any firm can succeed internationally. Future research should aim at deepening our understanding of early adopters of internationalization, which represent a widespread, ongoing trend.

Looking beyond a simplistic evaluation of success based on profits only, Oviatt and McDougall (1995) identified seven characteristics of successful global start-ups:

1. A global vision exists from the beginning that is easily communicated to others in the firm. Before a firm can be global it must think global.

2. Managers have prior international experience. Understanding of letters of credit, exchange rate risks and communication and cultural difficulties are necessary.

3. Strong international business networks. The network identifies opportunities, gives advice and assists in negotiations.

4. Preemptive technology or marketing is exploited. Born Global firms overcome economies of scale handicaps by having a distinctively valuable product or service.

5. A unique intangible asset is present. Sustaining the uniqueness of the product or service, usually through special knowledge or know-how, is important.

6. Product or service extensions are closely linked. Continual innovation allows the small firm to continue to exploit its niche market. 
7. The organization is closely coordinated worldwide. A strong top management team ensures that R\&D, procurement, production, marketing, distribution and sales are coordinated no matter how distant their physical locations.

Of 12 companies Oviatt \& McDougall (1995) studied, nine were still in operation or had been acquired two years after the study was conducted. The most important characteristics associated with success were global vision, international experience and a strong network. These characteristics were present in the successful firms from the beginning. Lack of a strong network, poorly functioning technology and lack of a unique intangible asset were cited as the cause of failure for the three firms no longer in existence.

\section{EMERGING MARKET CHARACTERISTICS AND BORN GLOBAL FIRMS}

Beginning in the 1980's, continuing through the opening of the Soviet bloc, and flourishing during the economic boom of the 1990's, global networking and global integration reached an unprecedented level of interconnectedness and dependence. At the state level, trade barriers are falling and international governing bodies like the World Trade Organization wield unprecedented influence. At the firm and individual level, consumer preference has converged in such a way that industries no longer need to think local but must act global (Yip, 2003). This convergence has certainly proven to be a boon to developed economies and multinationals alike. Two hundred years after Adam Smith's observation, developing markets are still in the process of taking advantage of the convergence of foreign commerce.

The World Bank uses level of income as the primary indicator of an economy's strength. Gross Domestic Product (GDP) is used to categorize countries into one of four categories. Countries falling into the lower middle and the upper middle ranges are prime candidates for the name "emerging market." GDP can be misleading as it does not take into account underground markets and exchange rate movements affecting comparison of GDP's in US dollars. Several key indicators, including GDP, give roundness to the definition of an emerging market and allows for a clear picture to surface. Growth rates, stage of development, and stability - or lack of it - taken together contribute to a useful definition of emerging markets (Olsson, 2002).

Emerging economies have typically been marked with rapid growth. Although several countries suffered during the late 1990's and early 2000's with currency crises, many others, notably China, continue to grow at breakneck speed. Increased transparency, deregulation, privatization of state enterprises, a burgeoning middle class, availability of consumer goods and the existence of financial markets all contribute to a countries stage of development. Lack of stability, either economically or politically, is common for most emerging markets. Countries experiencing political upheaval are hard-pressed to control their economy; countries without deep economic strength find it impossible to defend themselves against external threats.

Any country considered "developing" is not necessarily an emerging market. Some stand out as having advanced more quickly and made many of the necessary structural changes to ensure economic growth. These countries are poised for greater integration on the world stage. For the Born Global entrepreneur, these countries potentially offer the greatest opportunity for this type of firm. Broadly, the factors that make these countries attractive are their large populations, large resource bases, large markets and the fact that all of them are regionally powerful with strong geopolitical significance. These countries are actively seeking participation globally, both politically and economically, and acquiring the latest technologies in order to advance their global competitiveness. With the exception of communist China, all of these countries are struggling to build democratic institutions impervious to internal collapse. Their efforts to open their economies have occurred at different rates but all are working to transform state-run enterprises, develop economic policies of openness that spur competition and balance their budgets. Of course, there are many other developing countries that are regionally powerful with large resource bases, Russia for example, but the promise of legal, political and structural changes has not yet been borne out. The potential is there, but reality warrants caution when considering where to establish a Born Global firm.

The opportunities for Born Global firms in the next 10-15 years will grow for all countries but may grow exponentially in emerging markets. The most important emerging markets such as China, India, Mexico, Brazil, 
Turkey will be poised to capture most of that growth because they have done the difficult and, at times controversial, economic structural changes and reforms in order to take advantage of the global marketplace.

As noted by Bruno and Tyebjee (1982), facilities, transportation and living conditions in emerging economies all support the development of entrepreneurship in these countries. Collectively, these countries have spent billions on projects involving telecommunications, energy, transportation, water and sanitation, all with the assistance of the private sector. In the six year period from 1996 to 2002, Brazil and China invested almost half the total amount for all countries.

Developing economies can take part in the electronic commerce revolution by enacting regulations similar to those required for international trade, namely, an open economy that encourages competition. Internet use is expected to rise faster in developing countries over the next ten years than it will in industrialized nations. For Born Global firms, the Internet gives virtual proximity to industrial markets and reduces costs associated with business transaction. Liesch and Knight (1999) note the acquisition of appropriate knowledge is fundamental to successful market entry abroad, particularly for resource-constrained small firms. This information can be found on the Internet. In an example from the developed world noted by Oviatt and McDougall (1994), a software company in Australia with clients primarily in the US, allows purchasers to download their product directly from their website. Clients may receive the software via traditional methods if they choose but the ease and quickness of the download naturally makes this the preferred method. The ability to connect to the world from anywhere at anytime, distribute goods and services on demand and facilitate business transactions with very little cost gives entrepreneurs in developing countries a great opportunity to participate in the global marketplace.

Networks have been noted as an important element of the development of a Born Global firm (Gray, 1997). Networks, formal and informal, exist in all cultures and are a primary method of facilitating market transactions. Formal and informal networks share information about business opportunities, market barriers, and potential partners. The informal network serves a much more important purpose for developing economies where credit-rating agencies or chambers of commerce may not be available for screening of potential partners.

The ability for firms to enter and exit the market without oppressive regulations promotes growth and entrepreneurship. Developing countries generally require more procedures to start a new venture and subsequently, require a longer time horizon for full implementation of the new firm. This increases the cost of starting a new venture and encourages development of an underground economy as entrepreneurs seek faster, less bureaucratic methods of new business development.

As developing economies liberalize, they will be able to capitalize on more than just natural resources and labor advantages. Innovations will occur not only in developed nations but also in the most advanced developing countries. The ability to take advantage of the niche markets inherent in the Born Global phenomenon will become faster, easier, and less expensive.

Bruno and Tyebjee (1982) have identified twelve environmental factors that stimulate entrepreneurship. The presence of all of these factors is not necessarily required for entrepreneurship to exist, but the presence of many of them encourages greater levels of entrepreneurship and, in turn, economic growth. The twelve factors are: 1. venture capital availability, 2. presence of experienced entrepreneurs, 3. a technically skilled labor force, 4. accessibility of suppliers, 5. accessibility of customers or new markets, 6. governmental influences, 7. proximity of universities, 8. availability of land or facilities, 9. accessibility of transportation, 10. attitude of the area population, 11. availability of supporting services, and 12. living conditions. Developing nations can enact policies that support an increase in entrepreneurship, especially globally oriented entrepreneurship, and the establishment of entrepreneurial firms.

\section{ENTREPRENEURIAL ORIENTATION}

Many studies in the literature investigate why some small and medium sized firms get involved in international activity shortly after their inception (e.g., McDougall et al. 1994, Oviatt and McDougall 1994, Knight and Cavusgil 1996, Madsen and Servais 1997, Andersson and Wictor 2003). The distinguishing characteristic of these 
born global firms is that, shortly after they are founded, they seek to derive significant competitive advantage from the use of resources and sales of outputs in multiple countries (Oviatt and McDougall 1994). Several antecedents of such behavior have been identified. Entrepreneur/founder related factors include international vision of the founders (Mc Dougall and Oviatt 1991, Oviatt et. al. 1991), international experience of the founders (Oviatt and McDougall 1995), identification of a specific international opportunity (Johnson 2004), and desire to be an international market leader (Johnson 2004).

Is entrepreneurship a set of personality traits and behaviors or the processes and actions associated with the founding of a firm? The academic community has been trying to answer this question for some time. The trouble with explaining who (or what) an entrepreneur is stems from the multiple definitions of entrepreneurship. Various approaches have been taken since the field of entrepreneurship entered the business research vernacular - everything from individual traits to firm strategy has been considered the most appropriate unit of analysis. For the purposes of this paper, the unit of analysis is the individual. Bygrave \& Hofer (1991) define an entrepreneur as a person who perceives opportunity and creates an organization in order to pursue that opportunity. Gartner (1985) was one of the first to suggest that entrepreneurship is the result of individual traits (need for achievement, locus of control) activating a set of behaviors (locating a business opportunity, accumulating resources, etc.) that are interacting with the environment. An individual's entrepreneurial orientation is composed of personality traits (the internal environment), perception of the external environment (cognition) and actions or behaviors (manifestation of the internal into the external environment).

The personality traits most frequently associated with entrepreneurship are achievement motivation, locus of control, and propensity for risk-taking. McClelland's (1961) theory of the need to achieve and Rotter's (1966) internal locus of control are commonly applied in the study of entrepreneurship. According to McClelland, individuals with a high need to achieve want to solve problems, set targets and strive to meet those targets. Preference for challenge, acceptance of personal responsibility for outcomes and innovativeness are all associated with high need for achievement. Individuals with a strong need to achieve frequently find their way to entrepreneurship and are more successful in their ventures. Rotter's (1966) internal locus of control expectation is related to learning and supports active striving. Internal control refers to control over one's own life. Individual actions are dependent upon one's own behavior or one's own personality characteristics. Those with a strong internal locus of control do not feel controlled by luck or chance; their actions and the result of those actions are under their command.

Risk-taking propensity - the perceived probability of receiving the rewards associated with success of a proposed situation - is also a common trait identified in the literature as unique to entrepreneurs but is also more controversial than need for achievement and internal locus of control (both of which enjoy controversy within the literature). Mill (1891) was the first to bring the term "entrepreneur" into general use. He believed that direction, control, superintendence and risk-bearing were distinctly entrepreneurial functions. Although there is agreement that initiating a new venture can be a risky move, empirical support for risk-taking has been hard to come by. Brockhaus (1980) found that the risk-taking propensity of entrepreneurs is no more prevalent than in the general population. He found that moderate levels of risk are desired by entrepreneurs, but this is not incongruent with the general public. This dilemma, that entrepreneurs take risks but do not have a higher risk propensity, has yet to be resolved. Shaver \& Scott (1991) voiced skepticism at the methodology used to assess risk-taking propensity. They asserted that the scale used to measure risk was not designed to be used in this manner and, therefore, could not correctly measure the actual risk-taking propensity of entrepreneurs. This has led to a new take on risk-taking propensity and the way in which entrepreneurs look at risk. It boils down to this - entrepreneurs perceive risk differently because they use biases and heuristics (speculative formulation) to filter their decisions (Busenitz, 1999). Consequently, entrepreneurs fail to fully comprehend or fully acknowledge the level of risk associated with launching a new venture. This is an area requiring further research. Although the academic community has yet to find a direct link between risk-taking propensity and entrepreneurship, there is agreement on the fact that creating a new venture does involve risk. The entrepreneur's use of cognition heuristics in order to suppress the inherent risk of launching a business mediates between the internal (personality traits) and external (action/behavior) environments.

Mitton (1989) suggested there are nine observable patterns of conduct (behaviors) that contribute to entrepreneurial success. The "complete" entrepreneur, as he called it, has a big picture perspective, spots unique 
opportunities, makes a total commitment to their cause, sees a need for total control, views their actions in a utilitarian rather than moral dimension, are comfortable with and even welcome uncertainty, use their contacts and connections to open doors, embrace competence, and possess a special know-how. Mitten does caution, however, that these behaviors are exhibited by seasoned entrepreneurs. New entrepreneurs can model these behaviors to ensure greater success with their ventures. This leads to Propositions $1 \& 2$ :

Proposition 1: Entrepreneurs with high need for achievement in the global arena will found globally oriented firms.

Proposition 2: Entrepreneurs who found globally oriented firms will perceive their behavior as no more or less risky as the founding of a domestic firm.

\section{THE PROACTIVE PERSONALITY}

The proactive personality plays a key role for the entrepreneur operating in the context of an emerging market. A proactive personality is not constrained by situations and creates environmental change (Bateman and Crant, 1993). If an entrepreneur believes their environment is concrete and measurable (such as a developed, secure economy) analysis and data collection is used to discover the best possible strategy. On the other hand, a nondeterministic view of the environment invokes intuition, rule breaking, and qualitative factors to achieve success. (Becherer and Maurer, 1999). In a fuzzy environment, such as an emerging economy, the nascent entrepreneur may not follow a linear path to success. The ability to intuit ones environment and adjust accordingly, dodging the bullets as it were, may prove a more necessary attribute than an advanced ability to collect and analyze data. A fuzzy environment requires an ear-to-the-ground approach.

A proactive personality reflects the individual's orientation toward the environment. A proactive entrepreneur will scan for opportunities and takes a bold and aggressive approach to the market (Becherer and Maurer, 1999). The nature of the Born Global firm is one of scanning for opportunity and being aggressive in the marketplace. Bateman and Crant (1993) conceive of proactive behavior as a process that is foreactive more than counteractive, transcendent more than acquiescent, a means of primary more than secondary control, and as agency more than passivity.

The desire to overcome an environmental problem is directly related to proactivity, the extent to which people take action to influence their environment (Becherer and Maurer, 1999). The global entrepreneur must have a strong desire to surmount the structural limitations of an emerging economy and high levels of perseverance. This leads to Proposition 3:

Proposition 3: The more proactive the entrepreneur, the more perseverance the entrepreneur will exhibit in overcoming the environmental conditions of an emerging market.

\section{BORN GLOBAL ORIENTATION}

Over the years, the development of a set of characteristics described as a global orientation has been identified. The global entrepreneur in an emerging market will most certainly have a strong global orientation. Dichtl, Koeglmayr and Mueller (1990) first identified the "Foreign market oriented" exporter amongst a group of mostly domestic-oriented German small to medium sized firms. They found these managers experienced less psychic distance to foreign markets because they traveled more; had more education and were more proficient in a foreign language; did not feel job-related assignments abroad would have a negative effect on career and family; were less risk averse, adaptable and willing to change; and had a positive attitude toward exporting as a business strategy.

Gray (1997) describes global orientation as the awareness of and commitment to exploiting international business opportunities. Cavusgil and Knight (1997) have shown that managers of global firms have a bundle of global dispositions and competencies. These managers are expected to exhibit higher levels of risk tolerance in ambiguous situations such as those involved in internationalization (Cavusgil and Knight, 1997). Creating opportunity, and 
having and maintaining a positive attitude toward globalization is a direct extension of the experiences of global managers (Harveston, Kedia and Davis, 2000).

This bundle of experience includes international work experience, extensive international travel and schooling outside of the home country. Managers with these types of experiences tend to be more familiar with the foreign market conditions and opportunities available than managers without such experience (Harveston, Kedia and Davis, 2000) and are more likely to successfully enter a foreign market.

Physical presence is important. Managers with overseas responsibilities who remain in their home countries do not develop the same depth of understanding as managers who are required to live internationally. Managers with greater international business experience will also acquire the knowledge and skills to overcome culturally-related entry barriers (Gray, 1997). The ability to absorb and utilize information allows a small firm, like a Born Global, to level the playing field when faced with financial restrictions. Information can overcome a lack of resources (Liesch \& Knight, 1999). The Born Global entrepreneur, in having these international experiences, is able to build social and business networks to gather reliable information on market conditions and opportunities. The network, in providing information, supports the entrepreneur and allows the firm to overcome resource constraints. By accumulating international experience, the ability to build networks and relationships is strengthened (Oviatt, McDougall, and Phillips, 1995).

The ability to free the business from a single country or culture is a key element of the Born Global, and a key element of the founders thinking. A firm that is intrinsically "American" or "German" has rooted itself in a specific culture and place. The Born Global firm has freed itself from this type of identity. The global founder does not think of the firm in terms of it's "-ness." Founders and managers of these firms develop geocentric (worldcentered) mindset through international experiences and have interest in the world at large. This leads to Propositions 4:

Proposition 4: Entrepreneurs with a strong global orientation are more likely to found a Born Global firm.

\section{CONCLUSION}

Doing business in an emerging market is, quite simply, risky. Multinational corporations from developed markets expose themselves to risks the firm may not be capable of handling. Domestic corporations, having exploited their smaller home markets, may be in a position to compete globally but may find the resources they need isn't available. Skittish foreign investors may not take the chance on an emerging market firm and home market investors may not have the capital needed to launch a global effort.

Nevertheless, emerging markets present opportunities for Born Global firms whose founders have the above mentioned characteristics such as high need for achievement, proactive personality and global orientation. These entrepreneurs possess what is necessary to become successful in the turbulent and risky business environment of the emerging economies. Still, it should be noted that further examination of the Born Global entrepreneur is needed to better understand their driving forces in such environments.

\section{REFERENCES}

1. Andersson, S. \& Victor, I. (2003), Innovative Internationalization in New Firms: Born Globals - the Swedish Case, Journal of International Entrepreneurship, 1; pp 249-276.

2. Bateman, T. \& Crant, J.M. (1993), The Proactive Component of Organizational Behavior: A Measure and Correlates, Journal of Organizational Behavior, 14, 2; pp 103-118.

3. Baughn, C.C. \& Neupert, K. (2003), Culture and National Conditions Facilitating Entrepreneurial Start-ups, Journal of International Entrepreneurship, 1; pp 313-330.

4. Becherer, R. \& Maurer, J. (1999), The Proactive Personality Disposition and Entrepreneurial Behavior among Small Company Presidents, Journal of Small Business Management, 37, 1; pp 28-36.

5. Bell, J., McNaughton, R., Young, S., \& Crick, D. (2003), Towards an Integrative Model of Small Firm Internationalization Journal of International Entrepreneurship, 1; pp 339-362. 
6. Bilkey, W. J. \& Tesar, G. (1977). The export behavior of smaller Wisconsin manufacturing firms Journal of International Business Studies, 9 (Spring-Summer): 93-98.

7. Brockhaus, R. (1980), Risk Taking Propensity of Entrepreneurs, Academy of Management Journal, 23, 3; pp 509520.

8. Bruderl, J. \& Preisendorfer, P (1998), Network Support and the Success of Newly Founded Businesses, Small Business Economics, 10; pp 213-225.

9. Brunett, A., Kisunko, G., \& Weder, B. (1998), How Businesses See Government, Discussion Paper 33, International Finance Corporation.

10. Bruno, A. \& Tyebjee, T. (1982), The Environment for Entrepreneurship, in Encyclopedia of Entrepreneurship, pp 288-307, Prentice-Hall, Englewood Cliffs, NJ.

11. Busenitz, L. (1999), Entrepreneurial Risk and Strategic Decisions Making, The Journal of Applied Behavioral Science, Volume 35, 3; pp 325-340.

12. Bygrave, W. \& Hofer, C. (1991), Theorizing About Entrepreneurship, Entrepreneurship Theory \& Practice, Volume 16, Winter, pp. 13-22.

13. Cavusgil, S. T. (1980), On the Internationalization Process of Firms, European Research, No. 8, November, pp. 273-81.

14. Cavusgil, S. T. (1994). A quiet revolution in Australian exporters Marketing News, 28, (11), 18-21.

15. Coviello, N.E. \& Munro, H.J. (1995). Growing the entrepreneurial firm: networking for international market development. European Journal of Marketing, 29/7, 49-61.

16. Covin, J. \& Slevin, D. (1989), Strategic Management of Small Firms in Hostile and Benign Environments, Strategic Management Journal, 10; pp 75-87.

17. Crant, J. M. (1995), The Proactive Personality Scale and Objective Job Performance Among Real Estate Agents, Journal of Applied Psychology, 4 pp 532-537.

18. Dana, L. P. (2000), Creating Entrepreneurs in India, Journal of Small Business Management, 38, 1; pp 86-91.

19. Dichtl, E., Koeglmayr, H-G., \& Mueller, S. (1990), International Orientation as a Precondition for Export Success, Journal of International Business Studies, 21, 1, pp 23-40.

20. Garten, J. (1997), The Big Ten: The Big Ten Emerging Markets, First Edition, Basic Books, Harper Collins, New York, NY.

21. Gartner, W. (1985), A Conceptual Framework for Describing the Phenomenon of New Venture Creation, Academy of Management Review, 10, 4; pp 696-706.

22. Gray, B. (1997), Profiling Managers to Improve Export Promotion Targeting, Journal of International Business Studies, 28, 2, pp 387-420.

23. Harveston, P., Kedia, B., \& Davis, P. (2000), Internationalization of Born Global and Gradual Globalizing Firms: The Impact of the Manager, Advances in Competitiveness Research, 8, 1, pp 92-99.

24. Herron, L. \& Sapienza, H. (1992), The Entrepreneur and the Initiation of New Venture Launch Activities, Entrepreneurship: Theory and Practice, 17, 1; pp 49.

25. Jackson, J. \& Rodkey, G. (1994), The Attitudinal Climate for Entrepreneurial Activity, Public Opinion Quarterly, 58,$3 ;$ pp 358-380.

26. Johansen, J. \& Vahlne, J.-E. (1977), The Internationalization Process of the Firm - a Model of Knowledge Development and Increasing Foreign Market Commitments, Journal of International Business Studies, 8 , Spring/Summer, pp. 23-32.

27. Johansen, J. \& Wiedersheim-Paul, F. (1975), The Internationalization of the Firm - Four Swedish Cases, Journal of Management Studies, 12(2), pp. 305-22.

28. Jolly, V., Alahuhta, M., \& Jeannet, J-P. (1992). Challenging the incumbents: how high-technoloy start-ups compete globally Journal of Strategic Change, 1, 71-82.

29. Knight, G. (2000), Entrepreneurship and Marketing Strategy: The SME Under Globalization, Journal of International Marketing, 8, 2; pp12-32.

30. Knight, G., \& Cavusgil, S. T. (1996), The Born Global Firm: A Challenge to Traditional Internationalization Theory, Advances in International Marketing, Volume 8, pp 11-26.

31. Knight, G.A. (1997). Emerging paradigm for international marketing: the born global firm. Ph.D. Dissertation, Michigan State University, East Lansing, MI, USA..

32. Knight, G.A. \& Cavusgil, S.T. (2004), 'Innovation, Organizational Capabilities, and the Born- Global Firm', Journal of International Business Studies, 35 (2), pp 124-141.

33. Kobrin, S. (1994), Is There a Relationship Between a Geocentric Mind-Set and Multinational Strategy? Journal of International Business Studies, 25, 3; pp 493-511. 
34. Liesch, P. \& Knight, G. (1999), Information Internalization and Hurdle Rates in Small and Medium Enterprise Internationalization, Journal of International Business Studies, 30, 2; pp 383-394.

35. Lindqvist, M. (1991). Infant multinationals: The internationalization of young, technology-based Swedish firms. Unpublished doctoral dissertation, Stockholm School of Economics, Stockholm.

36. Littunen, H. (2000), Entrepreneurship and the Characteristics of the Entrepreneurial Personality, International Journal of Entrepreneurial Behavior \& Research, 6, 6; pp 295-309.

37. Lumpkin, G. T. \& Dess, G. (1996), Clarifying the Entrepreneurial Orientation Construct and Linking it to Performance, Academy of Management Review, 21, 1; pp 135-172.

38. Madsen, T.K. \& Servais, P. (1997). The internationalization of born globals: an evolutionary process? International Business Review, 6/6, 561-583.

39. McClelland, D.C. (1961), The Achieving Society, Van Nostrand, Princeton, N.J.

40. McDougall, P.P., Shane, S., \& Oviatt, B.M. (1994). Explaining the formation of international new ventures: the limits of theories from international business research. Journal of Business Venturing, 9/6, 469-487.

41. McKinsey \& Co.(1993) Emerging Exporters. Australia's High Value-Added Manufacturing Exporters, Melbourne: McKinsey \& Company and the Australian Manufacturing Council.

42. Mill, J.S (1891), Principles of Political Economy with Some of Their Applications to Social Philosophy, Volume 1, $5^{\text {th }}$ Edition, D. Appleton and Company, New York.

43. Mitton, D. (1989), The Compleat Entrepreneur, Entrepreneurship Theory \& Practice, Volume 13, Spring; pp 9-19.

44. Olsson, C. (2002), Risk Management in Emerging Markets, Prentice Hall, Pearson Education.

45. Organization for Economic Cooperation and Development (1999), Stimulating Private Enterprise in Transition Economies, Policy Brief, The OECD Observer; pp 1-4.

46. Oviatt, B. \& Phillips McDougall, P. (1994), Toward a Theory of International New Ventures, Journal of International Business Studies, 25, 1; 45-64.

47. Oviatt, B. \& Phillips McDougall, P. (1995), Global Start-ups: Entrepreneurs on a Worldwide Stage, The Academy of Management Executive, 9, 2; pp 30-43.

48. Oviatt, B.M. \& McDougall, P.P. (1997). Challenges for internationalization process theory: the case of international new ventures. Management International Review, 37/2 (Special Issue), 85-99.

49. Oviatt, B.M., McDougall, P.P., Simon, M., \& Shrader, R.C. (1991), A new venture without geographic limits: case history of a global start-up, in Curchill, N.C. (Eds),Frontiers of Entrepreneurship Research, Babson College,

Babson Park, 64-78.

50. Rennie, M. (1993). Global competitiveness: born global. McKinsey Quarterly, 4, 45-52.

51. Riddle, L. \& Gillespie, K. (2003), Information Sources for New Ventures in the Turkish Clothing Export Industry, Small Business Economics, 20, 1; 105-120.

52. Rotter, J.B. (1966), Generalized Expectancies for Internal Versus External Control of Reinforcement, Psychological Monographs, 80 1-28. In J.B Rotter (Ed.), The Development and Application of Social Learning Theory, 1982, Praeger Publishers.

53. Rotter, J.B. (1966), Generalized Expectancies for Internal Versus External Control of Reinforcement, Psychological Monographs, 80 1-28. In J.B Rotter (Ed.), The Development and Application of Social Learning Theory, 1982, Praeger Publishers.

54. S. B., Miles, G., \& Baetz, M. C., (1999). Explaining the international intensity and global diversity of early-stage technology-based firms Journal of Business Venturing, 14: 259-281.

55. Servais, P. \& Rasmussen, E.S. (2000). Different types of international new ventures. Paper presented at the Academy of International Business (AIB) Annual Meeting (November), Phoenix, AZ., 1-27.

56. Shaver, K. \& Scott, L. (1991), Person, Process, Choice: The Psychology of New Venture Creation, Entrepreneurship Theory \& Practice, Volume 16, Winter; 23-43.

57. Smallbone, D. \& Welter, F. (2001), The Distinctiveness of Entrepreneurship in Transitional Economies, Small Business Economics, 16; 249-262.

58. The World Bank (2002), Building Institutions for Markets, World Development Report.

59. Yip, G. (2003), Total Global Strategy II, Pearson Education, Upper Saddle River, NJ.

60. Yip, George, Javier Gomez Biscarri, \& Joseph Monti (2000), The Role of the Internationalization Process in the Performance of Newly Internationalizing firms, Journal of International Marketing, 8 (3), 10-35. 